International Journal of Linguistics, Literature and Culture
Available online at https://sloap.org/journals/index.php/ijllc/
Vol. 7, No. 4, July 2021, pages: $222-227$
ISSN: 2455-8028
https://doi.org/10.21744/ijllc.v7n4.1726

\title{
Synonymy in Modern Pharmaceutical Terminology of Uzbek and English Languages
}

Dilafruz Kabildjanovna Khudoyqulova ${ }^{a}$

Article history:

Submitted: 27 March 2021

Revised: 18 April 2021

Accepted: 9 May 2021

Keywords:

functional-semantic;

lexicography;

lexicon;

linguistic;

neologismsterm;

pharmaceutical;

pharmacy;

polysemy;

synonym;

word;
International journal of linguistics, literature and culture () 2021. This is an open access article under the CC BY-NC-ND license (https://creativecommons.org/licenses/by-nc-nd/4.0/).

Corresponding author:

Khudoyqulova, D.K.

Department of Uzbek Language and Literature, Faculty of Industrial Pharmacy, Tashkent Pharmaceutical Institute, Tashkent, Uzbekistan

Email address: khudoyqulova-1982@mail.ru

\footnotetext{
a Department of Uzbek Language and Literature, Faculty of Industrial Pharmacy, Tashkent Pharmaceutical Institute, Tashkent,
} Uzbekistan 


\section{Introduction}

Synonymy of a general literary language is understood as a coincidence in meaning or the presence of similar or similar meanings of a word. The most characteristic of the general literary language are considered stylistic synonyms, which "call the same thing, but correlate it with different concepts and, thus, through the name, reveal different properties of a given thing." Until recently, it was believed that synonymy as a phenomenon is not characteristic of terminology, and one of the primary requirements for a term was the absence of synonyms. This concept was once adhered to by D.S. Lotte - the founder of the Soviet terminological school and E. Wüster - the founder of the Viennese terminological school. The latter, later recognizing terminological synonymy, perceived it as one of the forms of connection between the signifier and the signified, but at the same time believed that such a connection should be one-meaning, that is, one term should correspond to only one term and vice versa (Shiukashvili, 2020; Atechi, 2017).

Since a term is not a special word, but only a word in a special function, it should be characterized by the same linguistic phenomena like any other word in the general literary language, and therefore also by the phenomenon of synonymy (Labruna et al., 2020; Murphy \& Andrew, 1993). In terminology, synonyms are correlated with the same phenomenon, concept, or object; they cannot characterize its various properties. In this regard, this phenomenon is recognized by some researchers as a terminological doublet. Synonyms in terminology have different natures and different functions. Here, as a rule, they are devoid of stylistic functions. The main factor in the appearance of synonyms (doublets) in terminology is often different sources of the formation of terms.

\section{Main Part}

The practice of the formation and implementation of terms is evidence that this lexico-semantic phenomenon is gaining more and more regularity for terminology, and this layer of vocabulary is characterized, as a rule, by absolute synonymy (Manase et al., 2012; Anderson \& Holcomb, 2005). This process is most characteristic of the initial stage of the formation of terminological systems when the natural (and artificial) selection of a more suitable term has not yet taken place and many variants are functioning at the same time. Terminological synonyms are characterized by absolute semantic interchangeability, as a result of which the terms - synonyms must be considered as completely identical in meaning and interchangeable in any context (Rasuljanovna, 2019; Wester, 1979). When a certain concept is within one specific sublanguage is endowed with several terminological expressions, a phenomenon of intra-industry synonymy is formed, which creates great difficulties in the work of translators and specialists involved in the systematization of scientific literature and documentation. Although in colloquial speech and a literary text synonyms are an integral means of stylistic expressiveness, however, in a scientific and technical text, as a rule, they are simply useless and therefore legally considered, starting from the time of D.S. Lotte, an unjustified and undesirable phenomenon. Despite this regularity, their number not only does not decrease but even increases, especially in the newly formed terminological systems.

It should be noted in this regard that certain concepts of medicine have several

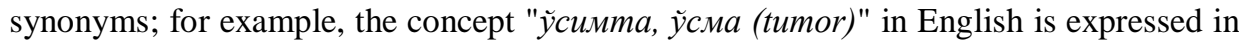
terms of tumor, mass, growth, swelling, neoplasm, formation, blastoma, growth, lump, rising, cancer.

Here are examples of the use of these terms in speech:

Neoplasm that hematogenously spreads to the choroid of the eye from an extraocular primary source (https://www.sciencedirect.com/topics/medicine-anddentistry/neoplasm).

The tumor has been resected along with a wide margin of normal tissue This mass is malignant.

How long have you had this benign lump? For a long time? - asked doctor Lawrence.

\footnotetext{
Khudoyqulova, D. K. (2021). Synonymy in modern pharmaceutical terminology of Uzbek and English languages. International Journal of Linguistics, Literature and Culture, 7(4), 222-227. https://doi.org/10.21744/ijllc.v7n4.1726
} 


\begin{abstract}
Cancer is a broad term. It describes the disease that results when cellular changes cause the uncontrolled growth and division of cells (https://www.medicalnewstoday.com/articles/323648).

A number of synonyms in the English language express the concept of "касал", "бетоб", "бемор" -disease, illness, sickness, ailment, disorder, trouble, mdistress, disturbance.
\end{abstract}

Here are examples of the use of these terms:

The clinical symptoms of this disease are misleading and rather unusual.

There may be a recent history of serious illness here. The illness has weakened her body. One can see an obvious manifestation of the ailment.

The backbone disorder is in an active phase. The history and character of the pain suggests rheumarism.

As a result of the study of the lexical-semantic process of synonymy in the sublanguage of medicine, it was revealed that its spread, especially in the newly emerging terminological systems, is due to the following extra-linguistic factors:

- a certain area of knowledge is being developed simultaneously in several different countries and with wide contacts, information is exchanged, and hence terms;

- in their works, many authors often introduce their own terms into circulation, in particular, to nominate newly emerging objects and concepts;

- the approach to the study of certain phenomena is carried out by scientists from different points of view, in connection with which, various characteristic features of one specific concept are recorded. That is why a separate part of synonymous terms are individual in nature. It is impossible to assess the current situation of the functioning of synonymy in scientific terminology as the indifference of linguists in this matter. However, today there is no definite point of view on the problem of synonymy in linguistics, even in such matters as its nomination and classification (Lotte, 1968; Melichar, 1988).

There are two contradictory positions on the variability of the nomination of terminological polylexy, which means the cyclical nature of names related to one signified:

- some use the concept of "synonymy" in all cases of manifestation of terminological polylexy;

- others reject terminological synonymy and consider all names related to one signified under the concept of "doublet".

The term "terminological synonymy" more identically explicates the presence of a number of nominations for one signified. Research of scientific texts and bilingual dictionaries on pharmacy according to such criteria as:

- the total number of the sample of terminological units,

- the volume of synonymous terms within this sample,

- the percentage of terminological synonyms to the total sample size,

- the total number of synonymous series.

- the maximum number of terminological synonyms within one synonymous series - made it possible to obtain the following data:

- The total number of synonyms in the medical terminology of the Uzbek and English languages is from 12 to $15 \%$, which in general is a fairly high indicator for terminology;

- The number of terminological units in the synonymous row varies from two to twelve;

- The total number of synonymous rows reaches approximately 300 synonymous nests;

- Synonymous relations are characteristic not only of simple and complex terms, but also terminological combinations and abbreviations (Khudoyqulova \& Akhmedov, 2021); 
- Both free and connected terminological combinations enter into synonymous relations. It should be noted that the expansion of the scope of synonymous series is carried out, first of all, due to terminological combinations of a free type, in other words, combinations that allow the substitution of one or two of the elements included in it (Kumar \& Foissner, 2015; Storjohann, 2009).

For clarity, we will demonstrate the following synonymous series, which includes international terminological combinations of a free and connected type, a national equivalent, as well as an eponymous term based on the material of the English and Uzbek languages:

Vitaminum A, or Retinoli acetas; Vitaminum B1, or Thiamini bromidum; Vitaminum B2, or Riboflavinum; Vitaminum B3, or Calcii pantothenas; Vitaminum B6, or Pyridoxini hydrochloridum; Vitaminum B9, or acidum folicum; Vitaminum B12, or Cyanocobalaminum;

A certain embodiment of lexical variance in the nomination of the same concepts of medicine took place in the initial period of the formation of the language of medicine in the three most significant varieties:

- when a number of borrowed units from different languages were used for one specific medical concept in the language;

- when, along with borrowing, the original word functioned in the language;

- when, with the emergence of borrowing, a Tajik word identical in meaning to it was specially formed.

All these expressions of lexical variance, according to the researchers, became possible as a result of disorganized, multidirectional linguistic connections and a course towards a conscious installation of comparative series of similar words.

- For the first type of lexical variation, the following series of pharmaceutical terms can serve as an example: pharmacy - medicine - drug - remedy - medicament - cure - preparation - дори воситаси, дори- дармон; pharmacy - drugstore - apothecary - dispensary - chemist's shop- дорихона, аптека.

- Second kind of variance (foreign language is the original word): weakness - asthenia - impotence - malaise - чарчоқ, холсизлик and so on;

- The third variety, which was characterized by the process of creation neologisms - equivalents to loan words. More recently, the term "validation" has appeared in pharmaceutical chemistry. And only specialists in this field will explain that validation is reproducibility, formulation is a dosage form in non-dosed drugs, as opposed to dosage form is a dosage form of a drug (Khayutin, 1974; Khudoyqulova, 2017).

Drug must be manufactured to the highest quality levels. The validation study provides the accuracy, sensitivity, specificity and reproducibility of the test methods employed by the firms, shall be established and documented (https://www.researchgate.net/publication/264634497_PHARMACEUTICAL_PROCESS_VALIDATION_AN_OV ERVIEW) (Chernyavsky, 1994; Flaişer, 1999).

Along with this, synonyms are the result of the synchronous functioning of two types of designation of a concept in medical terminology - full and short. In this case, the short form can be created either by lexical reduction of the terminological combination, or by replacing the combination with one-word designation (derivative, compound or compound word).

This is a natural situation in terminology for the emergence of synonyms in the language of science as a whole. This also includes cases of parallel functioning of the full form of nomination and its abbreviated form, for example:

GAMP - Good Automated Manufacturing practice - яхши автоматлашган ишлаб чиқарии амалиёти; GDUFA - Generic Drug User Fee Amendments - дори воситалари учун тугловларни ўзгартириш; GLP - Goоd Laboratory Practice - яхши лаборатория амалиёти; OTC - over the counter; as in medications you can purchase without a prescription -рецептсиз сотиладиган дори воситалари. A factor in the emergence of terminological synonyms is also the cases of the creation of so-called family terms and their varieties, formed on the basis of systematizing features of the concept:

Khudoyqulova, D. K. (2021). Synonymy in modern pharmaceutical terminology of Uzbek and English languages. International Journal of Linguistics, Literature and Culture, 7(4), 222-227. https://doi.org/10.21744/ijllc.v7n4.1726 
Teimurov pasta - Teimurov pasta, Vishnevsky's ointment, or Vishnevsky balsamic liniment - Linimentum balsamicum Wishnevsky, Parkinson's disease - Parkinson's casalligi, titration, etc.

\section{Results and Discussions}

The use of various names for one specific concept in a scientific and popular science context shows similarities with the general literary type of synonymy when it is implemented for stylistic purposes. Under such circumstances, the "incomprehensible" term in such texts is replaced by a more accessible variety for the general reader, or in the case of a popular presentation of scientific content, a widespread version of the term is first given, and then the actual scientific name of this concept is given. Such manifestations can often be observed in scientific or popular science literature.

In special terminological dictionaries, where terminological units are subjected to a special selection, taking into account the conditions that the term must meet, there are variants of names that differ in their "formal" and "colloquial". So, for example, in the terminology of medicine, terms function in parallel.

In the terminology system of medicine, semantic synonymy is mainly realized with its characteristic replacement functions, in particular, a borrowed term for an original term or a full version of a name for a short version; and refinement functions - an abbreviation and a terminological combination correlated with it, a family term and a term formed by selection of a classification feature of a concept (Akhmedov, 2010; Akhmedov \& Ataeva, 2020). Consequently, a comparative analysis of synonymy as one of the lexical and semantic processes occurring in the terminology of the English and Uzbek languages, made it possible to identify the following patterns:

- Synonymy is characteristic of the developing sublanguages of science and technology;

- This linguistic phenomenon in medical terminology is an active process and is of an interlingual nature;

- Synonymy has received special development in those terminologies that are formed on the basis of terminology systems of other languages, for example, the medical terminology of the Tajik language was created on the basis of Latin, English and Russian terminology of medicine;

- Polylexemic contacts within terminological systems, which were previously considered an undesirable phenomenon, have become quite widespread, especially in the newly emerging terminological systems.

The total number of synonymous series, as well as the volume of terminological units in each of them, depends directly on the degree of systematization of the terminology of a particular field of knowledge.

\section{Conclusion}

The results of the study are evidence that the phenomenon of synonymy is quite in demand and widespread in the terminology of medicine, and therefore cannot but be considered in the process of translation, as well as in lexicographic practice. From a semantic point of view, pharmaceutical terminology is subject to the phenomena of synonymy and polysemy, despite the requirements imposed by linguists on terminological units, such as unambiguity and the absence of units with the same meaning. Synonymy covers about $30 \%$ of pharmaceutical terminology in each language, which cannot be called insignificant.

\section{Conflict of interest statement}

The author(s) declared that they have no competing interests.

\section{Statement of authorship}

The author(s) have a responsibility for the conception and design of the study. The author(s) have approved the final article.

\section{Acknowledgments}

We are grateful to two anonymous reviewers for their valuable comments on the earlier version of this paper. 


\section{References}

Akhmedov, O. S. (2010). Lexical and semantic problems in the translation of tax and customs terms from English. // Philological sciences. Questions of theory and practice.

Akhmedov, O., \& Ataeva, N. (2020). Diachronic and simultaneous study of banking and financial terms. International Journal of Scientific and Technology Research, 9(2), 1193-1194.

Anderson, J. E., \& Holcomb, P. J. (2005). An electrophysiological investigation of the effects of coreference on word repetition and synonymy. Brain and language, 94(2), 200-216. https://doi.org/10.1016/j.bandl.2005.01.001

Atechi, S. (2017). Deceptive similarities between British English and Cameroon Pidgin English: A lexico-semantic investigation. International Journal of Linguistics, Literature and Culture, 3(4), 25-41.

Chernyavsky, M. N. (1994). Latin language and the basics of pharmaceutical terminology. Moscow: Medicine. $322 \mathrm{p}$.

Flaişer, M. (1999). The structure of the medical and pharmaceutical terminology in the Romanian language. Revista medico-chirurgicala a Societatii de Medici si Naturalisti din Iasi, 103(1-2), 246-250.

Khayutin, A. D. (1974) The term terminology and nomenclature. Samarkand, 1971. - 214.

Khudoyqulova D.K. (2017) Lexicographic interpretation of pharmaceutical terms and their meaning. Ilm sarchashmalari, 5, 91-95.

Khudoyqulova, D. K. \& Akhmedov O. S. (2021) Polysemantic Property of Pharmaceutical Terms in the Material Uzbek-English and Russian Text. International Journal of Disaster Recovery and Business Continuity, 12(1), 500-506.

Kumar, S., \& Foissner, W. (2015). Biogeographic specializations of two large hypotrich ciliates: Australocirrus shii and A. australis and proposed synonymy of Australocirrus and Cyrtohymenides. European journal of protistology, 51(3), 210-228. https://doi.org/10.1016/j.ejop.2015.02.002

Labruna, M. B., Onofrio, V. C., Barros-Battesti, D. M., Gianizella, S. L., Venzal, J. M., \& Guglielmone, A. A. (2020). Synonymy of Ixodes aragaoi with Ixodes fuscipes, and reinstatement of Ixodes spinosus (Acari: Ixodidae). Ticks and tick-borne diseases, 11(2), 101349. https://doi.org/10.1016/j.ttbdis.2019.101349

Lotte, D. S. (1968) Briefforms of scientific and technical terms. Moscow, 76-66.

Manase, M. J., Mitaine-Offer, A. C., Pertuit, D., Miyamoto, T., Tanaka, C., Delemasure, S., ... \& Lacaille Dubois, M. A. (2012). Solanum incanum and S. heteracanthum as sources of biologically active steroid glycosides: confirmation of their synonymy. Fitoterapia, 83(6), 1115-1119. https://doi.org/10.1016/j.fitote.2012.04.024

Melichar, M. (1988). Farmaceutickâ terminologie. 1. O smyslu, potïebë a vÿznamnosti farmaceu-tické terminologické prâce. Ces. Farm, 37(3), 138-142.

Murphy, G. L., \& Andrew, J. M. (1993). The conceptual basis of antonymy and synonymy in adjectives. Journal of memory and language, 32(3), 301-319. https://doi.org/10.1006/jmla.1993.1016

Rasuljanovna, I. N. (2019). The phenomenon of lacunarity as the linguacultural issue. prospects of world science2019, 226.

Shiukashvili, T. (2020). Comparative - contrastive analyze of anthropomorphic figures of evil in english and georgian languages. International Journal of Linguistics, Literature and Culture,6(1), 24-31. https://doi.org/10.21744/ijllc.v6n1.810

Storjohann, P. (2009). Plesionymy: A case of synonymy or contrast?. Journal of Pragmatics, 41(11), $2140-2158$. https://doi.org/10.1016/j.pragma.2008.09.036

Wester, E. (1979). Introduction to general terminology and terminological lexicography. / E. Wuester. New York. 215.

Khudoyqulova, D. K. (2021). Synonymy in modern pharmaceutical terminology of Uzbek and English languages. International Journal of Linguistics, Literature and Culture, 7(4), 222-227. https://doi.org/10.21744/ijllc.v7n4.1726 